\title{
THE GREAT OAK, THE WEAVING \\ MAIDENS AND THE RED BOAT, NOT TO \\ MENTION A LOST BRUSH
}

\section{Aado Lintrop}

The fact that I was audacious enough to make such a tremendous leap from studying the religions of the Eastern Finno-Ugric peoples to Estonian regi-songs is something that in a way I owe to the Estonian folk song researchers themselves. To this day we are still missing any significant treatment of very many folk-song motifs that could be interpreted as being mythological. To be sure, several folk-song types or motifs have been examined as part of a term paper, a graduate research paper or, and this is rarely, even a master's thesis; nonetheless, the focus in these works has always been on something other than religion. Furthermore, none of these works has been widely circulated. Only Tiiu Jaago's "The Golden Bride" has appeared in book form, but it was only intended as teaching material in the area of the stylistics of the regi-songs. Various articles on individual aspects of the mythology in regi-songs have been published by Oskar Loorits (in Finnish, on the "Golden Bride"), Uku Masing (on "The Christened Forest"), Felix Oinas (the majority of his work in English), Martin Puhvel, Jaan Kaplinski, Tõnn and Mikk Sarv. However, this is a surprisingly insignificant amount in comparison with the hundreds of articles devoted to the language and poetics of the regi-songs. In a way, I was also motivated to take a look at these songs by some statements found in Matti Kuusi's research work. For example, in his retirement lecture he summarized his long and extensive research on the "Sampo" as follows: "Despite my many years of effort, I have not succeeded in overturning Setälä's intuitive basic discovery, ${ }_{1}^{1}$ but I have adjusted it in places." (Kuusi 1994: 55). In commenting on the past and the future of the 'Finnish Method' Kuusi said among other things:

The critics of the 'Finnish Method' have often ironically drawn attention to how folklorists of this school, after a detailed analysis and careful examination of the various redactions, are still able to transform themselves in the very last pages of their work into prophetic visionaries and end up fabricating some synthe- 
sis of cultural history. The whole thing seems hopeless when verses recorded in Ingria in the 1800's as an incantation or as a girl's song have to be placed next to the spiritual milieu of the time of their inception along with all of the social relationships and significance that went with it. No one method of treating all the facts can lead to one hard and fast 'correct' result, the researcher must be satisfied with merely presenting a number of more or less probable hypotheses and choosing from them the one that seems at any given time to be the most explanatory (Kuusi 1980: $56)$.

The analysis of the following song fragments is not based on a textcritical method, comparisons of various redactions or on any other simply text-based method. I am convinced that neither these songs nor any one of their various redactions have ever embodied the traditional knowledge found in the world view that I am trying to capture a reflection of here. I will try to justify this position with the following short discussion.

Texts that are meant for transmitting the religious concepts and world view of any community from generation to generation (and within the community itself, perceptions of the world are never associated with religion, but rather are transmitted as factual information) should contain a low level of symbolization and poeticization otherwise they will not contain enough relevant information. At the same time, common to all religions (and all human religious experience in general) is that those things deemed inexplicable or mysterious get rendered into the language of words which requires a symbolic and poetic manner of expression. In order for a tradition to survive, this paradox must be resolved somehow. I suspect that traditional knowledge particularly crucial for a given community was (and is) transmitted in a pre-literate society in at least two modes, one of which is significantly more rule-oriented then the others. The information must be restated in different ways or it can even be translated into a different mode. We can take as an example of this the holy songs of the Khanty and Mansi that women and children were not allowed to hear. Despite this they still knew the contents of these songs but they were forced to transmit them in another form. Thus, a potential singer already from early childhood carried with him the contents of the songs in 
a reworked form. This may have been useful for him later in better understanding the songs and keeping 'tighter rein' on them to prevent the poetic-expressive aspects of the songs from taking over excessively. That for the Khanty and Mansi such mythological songs were primary from the point of view of transmitting traditional knowledge is evident from the fact that the hero of the stories was usually identified by means of stock phrases that were intertwined into the legends (see Lintrop 1997: 34-35). The mythological songs of the Papuans of New Guinea contain only hints and key words which are taught to the chosen individuals over an initiation process that lasts for years. Everyone was allowed to listen to the songs (as well as the stories told in the men's hut, since there were not any even remotely sound-proofed walls in Papuan villages), at the same time, the myths were kept secret. In this situation the initiated individual had to consider three distinct texts, the song itself, the concealed myth and the interpretation of the song by the uninitiated. We can perhaps state without exaggeration that for preliterate societies, in the transmission of their religious beliefs and world views, each performance is a recreation, and in this process, texts of at least two different modes converge; one mode is, from the point of view of the transmission of the traditional knowledge, the main channel of information while the others contain interpretation, commentaries, attitudes, evaluations. In order to compel the members of the community to continue transmitting the traditional knowledge, intracommunity institutions based on ritual and/ or rites are established, such as the Ob-Ugric Bear Feast, for example. A combination of text and ritual can result in invoking at some critical moment in an individual familiar with the tradition (but not necessarily one of its performers) a supernatural experience, which, poured into the mould of the tradition can in turn intensify the actuality of the tradition.

If for whatever reason one of the links in the chain is lost, the others cannot remain unchanged. If the mythological songs of the ancestors of the Estonians resembled the runic songs, which contain a high level of poeticization, then as far as the transmission of traditional knowledge was concerned, some other type of text must have been primary. As these texts disappeared or were transmuted, the songs lost their original point of contact with the actual religion. If on the other hand, the formerly mythological songs were 
less poeticized (as such they would have been the primary channels of transmitting the traditional knowledge) then a change in the songs must have come about as the result of a shift on the religious and ritualistic level. In either case, the song was no longer seen as one of the possible channels for transmitting information important to the community. It became valued now as a source of poetic expression for the singer, and in the cultural space of the Estonians this was accompanied by an increase of lyrical elements, a relatively greater degree of independence in the imagery (and as a result, in the ways of expressing this imagery), the absolutization of alliteration and the increased broadening of scope of parallelism, which resulted in the crystallization of the regi-songs as we know them. Their connection to religion was viewed from a totally new perspective. Now, in the best instance, they were the distant and shadowy reflection of times long past. As such they, or parts of them, were perfectly suited for entertainment or could be used for purposes of magic (for the latter purposes even totally incomprehensible texts can be used), but they were not used for expressing existing religious beliefs. For this reason a comparative approach to the textual analysis of the various song redactions cannot help us understand the background of their previous mythological content.

Now I can proceed on the premise that the Great Oak of the BaltoFinnic songs did not grow so much as a representation of the Great World Tree but rather out of the beliefs and customs associated with the yearly cycle. For this reason I will examine a number of the motifs found in the songs about the Great Oak, the Four Maidens and those connected with the summer (and winter) solstice(s). To these I will also add any necessary elements of customs and practice.

The heroes of many runic and regi-songs appear as brother and sister. Often the texts only offer indirect hints that what we have here are not ordinary people. The main characters in Ob-Ugrian legends are introduced in the same way. They often begin with the formulaic 'There lived a brother and sister', 'There lived a mos'woman with her brother', There lived a woman's son with his aunt/ grandmother'. Only through some stray hints does the listener find out that we are not dealing with mere mortals. Sometimes they 
remain unidentified right to the end of the story, sometimes they are identified in the end with stock-phrases borrowed from mythological songs, ${ }^{2}$ rarely are they identified directly by name. However, it is quite certain that in those legends with a mythological content, the sister or the mos'-woman represents some deity or mythical ancestor. The same applies to the brother. Since a great deal of the traditions associated with these individuals are transmitted by means of another genre of text (in the given instance the songs) it becomes difficult to understand the mythological background of the stories without recourse to the songs. If we now just suppose that the primary means of transmitting traditional knowledge in the Balto-Finnic cultural area was not through the songs then there had to be some other genre of text, which would have explained who the mythical sisters and brothers in the songs were. In the transformed shape that these fragments have survived to our day we can only find some stray hints to this.

Most often the story of the origin of the Great Oak begins with maidens, sometimes there are four (three) of them:
Oli ennen nel'l'ä neittä, koko kolme moršienta, Once there were four maidens, three brides in all, lähetih hyö heinän niittoh, they were sent to mow hay, eli korttehen koruh. to gather it together into stacks.
Vuokkiniemi (KKR I: 342)

The stock phrase Oli ennen 'Once there were' which appears quite consistently in many variants already suggests that we are not dealing with ordinary persons. Sometimes there is said to be a sillan täysi 'pier full' of them or as in Estonian variants, it is not explicitly stated how many of them there are:
Õekesed, hellakesed,
Sisters, dear ones,
lähme merda pühkimaie, mereääri äigamaie, let's go sweep the sea, clean the edges of the sea luuad kuldased käessa, with golden brooms in our hands, hõbedaised luuaoksad, broom straws of silver, vaskised olid luuavarred, siidised luuasidemed. Haljala (VK VI:1 142) broom handles of copper, broom strings of silk. 
We can assume that no ordinary maiden is going to be sweeping with a golden broom. Moreover, this golden broom can be ranked in the same conceptual class as the golden brush that appears in the song 'The Lost Brush':

Läksin kulles kuuskejeni, I, a golden one, went into a fir-tree, kallis kase latvajeni; a precious one, I went into the crown of a birch;

sealt suen sulaste päida, from there I brush the hair of farmhands,

kasin karja laste päida, comb the hair of shepherds, arin peada armutumalt, clean their heads ruthlessly suga kuldane käessa, óbedane täie lauda. with golden comb in hand and silver lice comb.

Jõhvi (ER I: 302)

An interesting metamorphosis occurs in the many variants of this song, the maiden addressing her brother becomes the sun in the crowns of the trees as she combs the heads of the herders with a golden brush. This transformation must number among the most vivid examples of what can result when lyrical elements make their way into what at one time were mythological songs. Matti Kuusi is of the opinion that the four maidens mowing hay are in all probability the same sort of maidens as the 'four maidens weaving' found in a common Balto-Finnic chain song (Kuusi 1963: 196). I believe that the maidens 'sweeping the sea' can also be placed with them as can the character with the 'golden brush' in the tops of the pines/ birches.

In Estonian regi-songs the motif of the 'four maidens weaving' appears in its most substantial form in the chain song 'The Sea beside our Yard (The Bone Ring)':

Mis seel sormukse sisessa? What is there inside the ring?

Neli noorta neitsikesta: $\quad$ Four young maidens:

üks seel kuab kuldavööda, one is weaving a golden belt, teine vaalib vaskivööda, the second is mangling a copper belt, kolmas poomib pollesida, the third is warping aprons, neljas nutab noorta miesta. the fourth is weeping for a young man. Haljala (VK VI:1 172) 
The Pleiades cluster located at the top of the tree or pillar supporting the starry sky is the most popular constellation in Estonian folk astronomy. Time was determined by them, weather conditions were predicted on their basis and in particular what the coming spring and summer would be like and whether there would be a good or bad crop that year. Distinct from the tree found in the 'Great Oak' song, the tree or pillar in this chain-song is a typical world tree. According to the beliefs of many peoples, the sources of celestial lights were found living or resting on or attached to the branches of this tree. This song chain quite clearly suggests that in the 'weaving maidens' we are dealing with celestial maidens. They have been variously associated with the Moirai of classical mythology or with the Old Scandinavian Norns (cf. Sarmela 1995: 212). A popular chain song from Ingria suggests that they may have been involved with human fate. To be sure, there is only one maiden weaving here:

Meroi meijen ikkunalla. Mikä uipi meroissa? Sotkoi tuo meroissa uipi. Mikä sotkoin siiven alla? Kätkyt sotkoin siiven alla. Mikä on kätkyen sisässä? Poikoi kätkyen sisässä. Mitä poikoi tekköö: kirjoikantta kirjuttaa. Mikä kirjokannen alla? Neitoi kirjoikannen alla.

Mitä neitoi tekköö? Kultoikangasta kuttoo, hopeaista helkyttää. Taittui yksi kultoilankoi, helähtyi hoppealankoi, neitoi täytyi itkömään. Hevaa (SKVR IV $:$ :441)
There is a sea under our window. What is swimming in the sea? A duck is swimming in the sea. What is under the duck's wing? A cradle is under the duck's wing. What is in the cradle? A boy is in the cradle. What is the boy doing? He is decorating a multi-coloured lid. What is under the multi-coloured lid? A maiden is under the multicoloured lid.

What is the maiden doing? She is weaving a golden cloth, she is flashing a silver cloth. A golden thread was broken, a silver one was snapped, the maiden burst into tears.

What follows is a description of how the tears fall onto her cheeks, from there onto her brooch, from her brooch onto her stockings. In place of kirjokanne 'multicoloured lid' many variants have kirjan 
kansi 'cover of a book' which scholars consider to be a later transformation (cf. Setälä 1932: 154). In my opinion however, we cannot rule out the possibility that this is a book or artifact where the days of a person's life are recorded. This is quite a widespread piece of imagery. Compare for example the following from Khanty folklore:

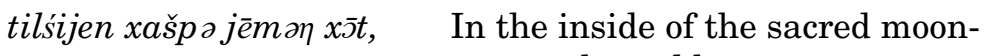
coloured house

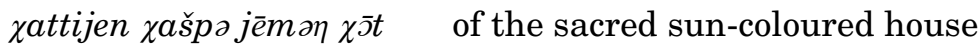

in tipetna,

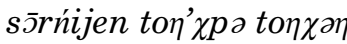

pasan in strotna,

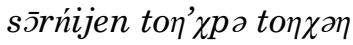

pasan in ü tetna,

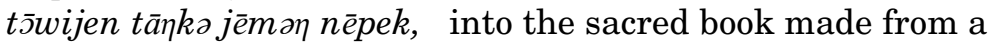

spring squirrel's skin

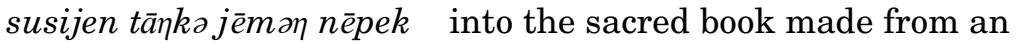

autumn squirrel's skin

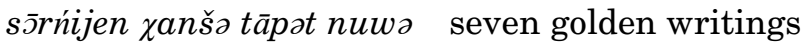

$\bar{u}_{R}$ tam $\chi$ anšijattat, the lord is writing

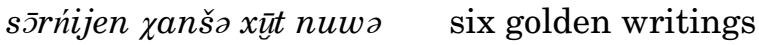

tuw tam qanšijattat. he is writing there.

(Steinitz 1939: 340-341, verses 25-37.)

Here we are dealing with the 'World Surveyor Man', the deity closest in proximity to humans. He takes care of people's welfare and is the intermediary between humans and Kaltash-Anki who keeps accounts over people's lives and determines how long they will live. The World Surveyor Man keeps a record of human deeds (among other things the offerings they bring) and begs his mother not to lessen the days allocated to them, particularly those allocated to

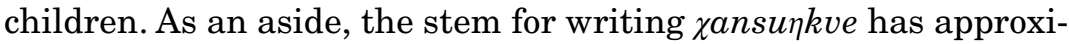
mately the same range of meanings as the comparable Estonian stem kirj-. For example, both can mean both writing as well as making a repeating pattern. The adjective $\chi$ ansa $\eta$ is both multicoloured as well as patterned. The maiden in the Ingrian song, who weeps over the broken thread might well symbolize a deity grieving over the severing of a human life. The multicoloured lid could well signify the sky but the sky could also be the place where 
human lives are recorded. According to a very popular belief, stars are considered to be the souls or lives of humans:

There are said to be as many stars in the sky as there are people on earth. Whenever a star falls from the sky, a person dies. Because along with a person's death that person's soul star also goes out. Big and bright stars are said to be the souls of rich people and small dim ones are the souls of poor people. ERA II 132, 597/8 (8) Krj.

Another song, recorded in Ingria in the 80's of the previous century, tells how a maiden leaves home to go walking, hits her foot and sits down crying. Gold, silver (and copper as well) invite her to come with them, but she goes with her younger brother:

oroi juoksi, matka joutui, The stallion ran, the trip advanced, reki liukui, tie lyhheeni. the sledge glided, the road shortened.

Ajoi Kuutarmoin kujalle, He rode into the yard of the Moon

Mistress,

Päivöttären tanhavalle - onto the street of the Sun Mistress.

Kuuttarin tytär kuttoo,

The daughter of the Moon Mistress is weaving,

kultoikangasta kuttoo, she is weaving a golden cloth, hopiaista helkyttää.

Taittui yksi kultoilanka, helkähti hoppiialanka.

Täytyi neitoi itkemää.

Soikkola (SKVR XV: 534) she is flashing a silver one. A golden thread broke, a silver thread snapped, the maiden burst into tears.

In the above song the weaver is clearly associated with the Sun and the Moon. In some variants three rivers are born from her tears, two (or three) hills where three birch trees grow and on top of the birches three cuckoos sing:

Yksi käki kullin kukkui, One cuckoo calls golden, toine huohteli hoppein, the second sings silver, kolmas käki leinin liekkui. the third swings in mourning. Soikkola (SKVR XV: 536)

Later the cuckoos are associated with father, mother, the brothers and sisters and we are told which cuckoo calls for which person (= what fate awaits which person). And thus the connection between 
the maiden weeping over the broken thread and human fate is even more apparent.

In Karelia the following chain is added to the 'Great Oak' motif:

Pilveš on pisarat šuuret,

pisareš on luojat lammit,

lammis on veno punani, venosessa on nuoret miehet,

nuoret miehet naimattomat, viel' on viinan juomattomat.

Punotah punaista köyttä, šituvo meren šivuva, Kannanlahta kuakistuae: meri tyynenä pysyise, Kannanlakši kaunehena. Vuokkiniemi (KKR I: 342)
There are great drops in the cloud, in the drops are wide ponds, on the pond is a red boat, in the boat there are young men, unmarried young men who have not drunk liquor yet. They are braiding a red rope to tie up the shores of the sea, to choke Kanna Bay, to keep the sea calm, to keep Kanna Bay beautiful.

Without a doubt these young men do not represent people either but rather beings from a supernatural sphere who determine among other things whether the sea is calm or stormy. At the same time they are associated with the sun since the red boat as well as the red rope they are braiding refer either to the dusk or dawn sky. A red sky has always been an omen of the weather. Even today it is believed in many places that if there is a red sky in the evening then the next day will be fine. The chain in the Estonian song 'The Burning of Gold' suggests that we are dealing with beings that can influence the weather. They have power over the rains that can put out fires:

Pilves on veepisara, pisaras on puhas purje, purjes on hani madala, hanel on saba sinine, sava pääl on saksa sängi, saksa sängi, kuldamängi, sääl mängib Sulevi puega, Sulevi, Kalevi puega.

Haljala (VK VI:1: 164)
There is a drop of water in the cloud, in the drop there is a clean sail, in the sail there is a humble goose, the goose has a blue tail, on the tail there is a nobleman's bed, a nobleman's bed, a golden game, there the son of Sulev is playing, there the son of Sulev, the son of Kalev. 
Incidentally, in some versions a maiden/maidens weaving the belt have been placed into the bed (VK III:1:114 Kuu, VK VI:1: $166 \mathrm{Hlj}$, ERlA II:1: 234 Äks). And in the song 'Let's go Haying for the Creator' the maidens 'receive gold from the Creator's (God's) mown hay/ Mary's meadow' (ER1A II:1:231-232). In 'The Miracle Worker' the individual braiding the rope that connects the earth with the sky is sometimes a smith or the son of God/Mary.

It might be significant that four (three) maidens and three youths figure in many Karelian songs about the origin of 'witch's arrows' (lumbago). Often their numbers are expressed by the following:

Sisarest on sillan täysi, There is a pier full of sisters, veikkoja veno punanen. a red boat of brothers Suistamo (SKVR VII $:$ 366)

And even variants such as the following can be found:

Oisko meitä toine moine, If there were a few of us, sisareksii sigla täysi, veljeksi veno punane, a sieve (the Pleiades) full of sisters, a red boat of brothers.

lähemmä heinoi niitäntäh, Let's go mow the hay, korttehien koguontah... gather it into stacks.

Suojärvi (SKVR VII 4399 )

If we accept that the mowers/sea sweepers are not ordinary humans, we can then associate the sisters with the celestial weavers and the brothers with the young men sitting in the red cloud boat (in the dusk or dawn sky). The mown and raked hay gets burned and an oak grows out of the ashes. A significant detail is added to some Karelian variants where the ashes are first of all set aside for the Sun or the Son of the Sun to wash his hair with:

Jää siïa vähä poroa pestä pojan päivän päätä, silmiä hyvän sikiän. Pesi pään pelvopioksi,

kaklan lumi kavuksi, silmät siiromaitokseksi. his eyes into flowing milk. Suistamo (SKVR VII $:$ :359)

Some dust is left over the good procreators eyes. of flax, flax,

to wash the hair of the Sun's son,

He washed his hair into a handful

his neck into snow-white bundles of 
Minne, kunne tuhkat pannah?

Loaji pikkune poroja.

Miksi porot pannah?

Päivälle hyvälle peätä pestä,

sigivölle hyvälle silmii pestä.

Pesi peän pelvoi pivoks,

silmät liinan siemeniksi, kaglan kanan muniksi, muun vartalon muiks hyviks. Suojärvi (SKVR VII : 399-400)
Where, oh where to put the ash?

A little bit of dust was made from it.

What was the dust for?

To wash the hair of the good Sun,

to wash the eyes of the good procreator.

He washed his hair into a handful of flax, his eyes into linen seeds, his neck into hens' eggs, his body to other good things.

In many texts the Sun (Son of the Sun, and in its parallel verse the good procreator/begetter) washes his hair into a handful of flax and his neck into hens' eggs. I believe that the mention of flax in connection with the hairwashing is not just merely a poetic image. Around the time of the summer solstice magic methods were employed to try to influence the growth of flax. On Whitsunday or the eve of Whitsunday, the Votes would light bonfires. Maidens would strike the fire three times with switches each time saying 'mudrushes into the fire, flax onto the fields' (Ariste 1969: 75). In Estonia mud-rushes were symbolically thrown into the fire on St. John's eve. A report from Saaremaa describes this in the follwing way:

Three sticks are thrown into the St. John's eve bonfire. While throwing the first one you say 'mud-rushes into the fire', with the second one you say 'bent hay onto the fallow' and with the third one, 'flax onto my field' (RK IV: 66).

In Tõstamaa flax plants were thrown into the fire (ibid.). Eggs were coloured at Whitsuntide both in the Vote territory as well as in Estonia (Ariste 1969: 75; RK III: 213). Similarly, haying suggests a period close to the summer solstice (John is coming with a scythe, Mary is following with a rake. Karja. RK IV: 93). Hay mown on St. John's day or just before was imbued with special powers (RK IV: 28). I assume that the summer solstice like the winter solstice was 
not associated with only the actual solstice itself but rather was more extensive. Among the Udmurts for example the winter solstice vozhodyr lasted from 7-19 January (Christmas Day until Candlemas), the summer solstice invozho lasted from Pentecost to St. Peter's day. Perhaps the following verses found in Karelia refer to the bonfires of the solstice:

Tuliba tuuli Tuulloksesta,

ahava Aunuksen muasta, tungi heinäset tulehe...

Suistamo (SKVR VII $: 362$ )
A wind came from the land of the winds, a cold wind from Olonets, pushed the hay into a fire...

The washing of the Sun's hair can be ranked in the same poetic class as the combing of the hair and the sea sweeping. Now, coming back to Estonian regi-songs, if we suppose that sea sweeping is on the one hand a metaphor for the movement of the sun low over the sea (cf. the combing of hair in the song 'The Lost Brush'), and on the other hand also the expression of a concrete magical activity performed around the summer solstice, we arrive at a schema whereby the 'Great Oak' is born during the period of the summer solstice. We can find support for this in the customs associated with this period: just prior to Whitsuntide floors were washed with special care, the yard and footpaths were swept clean (RK III: 213). Among the Votes the yard was swept clean as well on Whitsunday eve (Ariste 1969: 76). On St. John's day particular attention was placed on housecleaning (especially on scrubbing floors, RK IV: 28). The sweepings were often the objects of magic activities:

Külatüdrukud, õeksed, külanaesed, naesukesed, võtame kuldsed luuad kätte,

hõbedased luuavarred, siidised luuasidemed!

Lähme merda pühkima, mere ääri äigama!

Pühime pühked põlle sisse,

viime pühked karjaaida!
Village maidens, dear sisters, village women, dear women, let's take golden brooms in hand, silver broom handles, silken broom strings! Let's go sweep the sea, clean the edges of the sea! Let's sweep the sweepings into our aprons and take the sweepings into the pasture! 
Siin küll tõuseb tõmmu karja, Then surely the herd will grow swarthy, sead siunakad-libedad... the swine so snaky sleek...

Karuse (ERlA II: 1 204)

The motif of bringing trees into the house for the holidays found in the song 'The Lost Brush' can be associated with Whitsuntide, which in M. Hiiemäe's opinion marked the summer solstice (RK IV: 16)

Hellakene vellekene, kui kuuled pühad tulema,

ajad kallid ajamatoo siis kuused kodusse, kased kammerde edeje! Too sa kuuski kuusi sülda, kaske too kaheksa sülda, sada sülda sangaleppa, tuhat sülda turdaleppa! Ma lähen, kulles, kuuskejeni,

kallis, kaselatvajeni.

Seal soen sulaste päida,

harin päida armetuila, kasin karjalaste päida. Pilistvere (ERlA I:2: 301)
Dear brother, dear loving one, when you hear of the holidays coming,

the precious days approaching bring fir trees into the house, birches in front of the chamber! Bring a six-yard fir, bring an eight-yard birch, a one hundred-yard alder, a thousand-yard black alder! I, the golden one, will go into the fir, the precious one, into the crown of the birch.

From there I'll comb the hair of the farmhands, brush the heads ruthlessly, smooth the shepherds' hair.

The stock-prase Jaanikene, kaanikene, tee mul saksa saanikene 'Dear John, dear blossom, make me a gentleman's sledge' furthermore points to St. John's day.

In a song collected in the last century in Ingria, the season for combing hair is delimited in the following way:

Mänin rannoille kesoilla, I went to the shore in the summer time,

keski kesoilla, heinajalla, at midsummer, during haying time, paraalla paistehella... in the best sunshine...

Soikkola (SKVR XV: 393) 
The sweeping of the yard and footpaths in human time is comparable to the sweeping of the sea and the path of the sun (the edge of the sea) in the realm of the deities. It is possible that we have come full circle here because the chips from the chopping of the 'Great Oak' fall into the sea (in Finnish and Karelian variants) and in this way they can end up under the brooms of the sea sweepers. The maidens mowing hay also find a magic love leaf / oak chip.

Oli ennen nel'l'ä neittä, koko kolme moršienta, lähetih hyö heinän niittoh, eli korttehen koruh.

Löyvettih hyö lemmen lehti, lemmen lehti, tammen laštu, pantih mualla kašvavalla, arolla avaralla.

Sieltä kašvo kaunis tammi, yleni vihanta virpi,

pietti pilvet juokšomašta, hattarat hačertamašta. Vuokkiniemi (KKR 1: 342)
There were once four maidens, three brides altogether, they went to mow hay or gather it together into stacks.

They found a magic love leaf, a magic love leaf, an oak chip. They planted it in the ground into a wide meadow.

A beautiful oak grew from it completely covered with green boughs

hindered the clouds from fleeing, small clouds from going.

Taking everything above into consideration, I believe that all of those scholars who have connected the 'Great Oak' to the Milky Way (the first to do so was U. Harva in 1918) are right. However, I do not think that it is a story of how the Milky Way came about in the usual sense of creation stories since the emphasis is not so much on where or how it got its beginning (compare for example the story of the origin of iron) but rather it establishes the connection between the origin of the 'Great Oak' with the yearly recurring cycle of time. I believe that the 'Great Oak' of the Balto-Finnic peoples expresses above all the alternation between the light and the dark that results from their boreal location. This is the yearly cycle that is represented as the growing up and chopping down of the giant celestial tree. I believe that what motivated the development of this image was not so much what direction the branching Milky Way pointed at any given time but rather the fact that the Milky Way only becomes visible when the nights get longer and darker so 
that by the winter solstice on a clear night you can see it for the greater part (17 hours) of the diurnal cycle. We can then see in the silver roost and the golden pole of the St. Martin's day songs the Estonian parallel to the Archangel Karelian song lines:

Jo on tammi koatununne

poikki Pohjoiseñ jovešta

sillakši iku-šijahe, männä miehem matkalaiseñ

pimiäh om Pohjolahe, miešten süöpähä külähe, urošten uponnehehe.
Now the oak has been felled across the river of the North a bridge to a timeless place for a man a-travelling to go to the dark North, to the man-eating village, to the place that had drowned a hero.

Uhut (SKVR I $\left.\mathrm{I}_{4}: 470\right)$

After all, if you can go across the bridge you can also come that way too. Incidentally, the Estonian name for the Milky Way, the 'Bird Way' contains a hint that it is the connecting path between the living and the dead. We have to consider the special meaning of the solstice. The time around both the summer and winter solstices was significant because at other times of the year the boundary between the world of humans and the supernatural sphere was not as clear. It has found its most vivid mode of expression in the Time of the Souls of the Estonians - during the darkest part of the year when on snowless nights the Milky Way (Bird Way) was most visible. I think that one of the reasons for the fact that the BaltoFinnic All Souls' Day shifted to an earlier period from the winter solstice lies in the local climate that does not allow for a permanent covering of snow in November and as a result this pre-snow period seems to be the darkest time of the year. Among the Udmurts, who live in a continental climate, the Time of Souls vozhodyr was the period after Christmas when it was believed that supernatural beings - vozho's - visited the villages and lived in the saunas. ${ }^{3}$ Christmas mummers went through the village then. The connection between the vozho's and water is significant. It was thought that they actually came and went along the rivers (in some places they were even considered to be solstice water spirits). The whole winter solstice period ended with a holiday jö vyle sulton 'standing on ice' or vozho kel'an 'seeing the vozho's off'. On the evening of this holiday the people went through all of the saunas and said pot tatys' milemestyles' 'go away from among us'. The next morning 
they went onto the ice of the river, beat on the ice with stakes and shouted koshki tatys' 'go away from here' (Pervukhin 1888: 104106). The solstice visitors were exorcized into the water and down the river in this way. There are traces in the Udmurt religious system that the dead were also believed to depart by going downstream. A very widespread image is of water (a river or the sea) as the dividing boundary between the realm of the dead and the land of the living or as the way to the land of the dead. All of the songs mentioned above are also connected with water, the comb falls into the sea, the sea is swept, there is a pier full of sisters / a boat-load of brothers, the 'Great Oak' grows on the back of a 'Great Pike', the 'Great Oak' is on an island, the 'Great Oak' falls and become a bridge, etc.

Even though we might see certain signs of some deity with compassion toward humans in those maidens who were crying for some young man gone to war or because of a broken thread, nonetheless, the maidens are related to each other in that their activities all precipitate death. The sun / maiden looking for the comb in the sea often finds a sword, ${ }^{4}$ the thread breaks in the hands of the weaver, the cuckoo calls out mourning, the chopped down oak becomes the road of the dead, the chips from the oak (often the very first chips to fall as the oak is being chopped) are turned into the witch's arrows (lumbago) that in the hands of a blind shooter hit a human:

Kolm' om poikoa pahalla: The evil one has three sons: üks' on rujo, toin' on rampa, one is cripple, the second lame,

kolmasi peri-sokie; rujo jousta jännittävi, rampa nuolie vanuvi, ampuja peri-sokie.

Saipa nuolet valmeheksi. Ampu kerran nuoliañsa taivosehe peäsä peällä. Sepä katko ilman koaret, tahto taivoni haleta; ei sitä sieltä peritä! Ampu toisen nuoliasa moa-emähä jalkohoiñsa; the third completely blind. The cripple son flexes the bow, the lame one makes the arrows, the completely blind one shoots them.

When the arrows were ready he shoots the first of his arrows onto the head of the sky about and broke the rib of the sky, the sky was ready to split. It will not be returned.

He shoots the second of his arrows into the legs of the earth mother. 
moa oli Manalla männä, The earth nearly went to the underworld,

kankas kahtia hajota; the mantle nearly cleft in two.

ei sitä sieltä peritä! It will not be returned.

Ampu kolmannen nuoliañsa He shoots the third arrow

kohti vuorta korkieta, toward a high mountain,

vasten varvikko-mäkie; against a piny hill;

nuoli kilpestih kivestä

ihohon inehmi-raukan;

the arrow bounced off a stone

into a poor person's flesh.

se sieltä perittänehe.

It will be returned from there.

Vuonninen (SKVR I 4 459)

In some eastern variants the oak is born directly from the hairs of the maiden of the North / the Land of the Dead and / or from the teeth of her comb (again the hair combing motif). In some songs the place where the oak grows is in the North or in the Land of the Dead. In some northern variants it is a bird of prey from the north (Lapland, Northern Norway) or a Laplander who sets the hay on fire. Darkness is the usual characteristic of the Land of the Dead in perhaps all religions. We find a widespread connection between trees and death in the image of the World Tree that often gets mixed up with the Tree of Life.

The four (three) maidens of the songs who are weaving/sweeping the sea / mowing the hay symbolize supernatural beings responsible for the changing of the seasons, the passage of time and human fate. It is not possible to determine their concrete counterparts in mythology, but it is more than likely that they did not exist in the present form. In considering the alternation between the sun and the maiden in the song 'The Lost Brush' and the celestial weavers in the chain 'The Sea by our Yard', they might on occasion be the poetic counterpart to the celestial bodies (such as the sun, moon, morning and evening stars) themselves. The belt weaving found in many songs is the best metaphor for expressing the passage of time (life). It also allows for the parallel image of a hair comb, or a weavers slay as well as these two activities.

I believe that with the pillar/oak that supports the sky in the chain song and the giant tree of the 'Great Oak' song, we are dealing with three different archetypical images that have become mixed. These have found expression in the beliefs associated with the world tree 
and the tree of life found all over the world. These images have been shaped by a) the idea of a tree, pillar or mountain (the axis of the world) supporting the sky and/or celestial bodies, which in the case of the image of the world as a layered universe also becomes the path connecting the various spheres, $b$ ) the belief in trees that in one way or another are able to confer death or immortality, and last but not least c) myths about deities through whose agency or activities (including their death and rebirth). The alternation between night and day and the changing of the seasons can come about.

This last archetype is indirectly contained in the motif of the origin of the 'Great Oak' where the tree starts to grow in the spot where beer foam has been poured out under a father's window, a brother's gate, or on the path to the well. According to the usual patterns found in the folksongs, the later allows us to assume that the person who pours the foam is a female. This is also suggested by the song variants where the beer is brought in small beakers:

Olin joutossa Jumalan, I was at god's revels, piossa pyhä Kalervo, tuotii tuopilla olutta, pikarilla pienimmällä. at Holy Kalervo's party, beer was brought to me in a stoup, Narvusi (SKVR III 1 : 329)

The fact that in asking for help (in chopping down the tree) a brother is invoked, sometimes it is even quite explicitly stated that 'I had a single brother, a single little brother, like other girls' (same song) leaves no room for doubt that it was a maiden who arrived at the party of the gods. But what sort of a female being could attend such a drinking party? Most likely the sort of being such as we have in the celestial weaver or sea sweeper. If we assume that the dropping of the comb in the sea (respectively, looking for the lost brush), the sweeping of the sea and the growing of the Great Oak express one and the same process or different stages of the same event, we can then thematically connect the two songs below:

Oli mul üksi ainus venda. I had a single brother.

Kuulis ta pühad tulevad, He heard that the holidays were on their way,

kalli aegu arvatavad: the precious day were approaching, 
ta tõi kuused ju koeasse, kased kamre lääve alla.

Võtsi ma arja ju piosse, vaske raua kaindelusse, läksi kuldse kuuse otsa... he brought fir trees home, placed birch trees under the threshold of the chamber.

I took a brush in my hand, a copper tool under my arm and went into the crown of the golden fir...

Hanila (ER I: 325)

and

Jouduin juottoon jumalan, I arrived at god's revels, käräjään Väinämöisen, Väinämöinen's jamboree, piiruun Pyhän Kalervon. the party of holy Kalervo. Tuotiin tuopilla oloja, A beer was brought to me in a stoup, pikarilla pienimmällä. in the smallest of beakers, Hiiv oli alla, vaahto päällä...the yeast was below, the foam was

Soikkola (SKVR III 1 : 166) on top...

M. Kuusi associates this party motif with the wedding of the Sun and the Moon, a theme borrowed from Baltic folklore (Kuusi 1963: 142-146). Without attempting to argue against the influence of Latvian and Lithuanian folklore here, I merely want to point out that the Sun appears as a female being among the mythologies of more eastern Finno-Ugric peoples as well. Formerly the word for wedding 'pulm' did not necessarily have the same connotations that it has today or even a hundred years ago. It is quite possible that this word was used once for indicating all manner of different rituals. For example the word for wedding in Udmurt s'uan can be used in connection with the rituals performed when moving into a new house (korka s'uan), dedicating a new prayer house (mudor s'uan), at the end of the spring planting (buso s'uan) or when bringing offerings to the dead (val s'uan). Moving the sacred grove (lud, keremet) to another place as well as making offerings to dead ancestors (jyrpyd s'oton) was accompanied by a wedding procession. In addition to this, the Udmurts also believed that the water and forest spirits hold weddings twice a year. In Estonian the word for wedding 'pulm' has also been more widely used (perhaps the word for massacre, blood bath verepulm ${ }^{5}$ contains a hint to this effect). It is conceivable that in its original usage, the word could have been 
used in connection with certain rituals performed around the solstice. But even if in the Balto-Finnic cultural continuum the word pulm did not have such an extensive range of usage, it is possible that as a relatively neutral ritual as far as religion was concerned, with the coming of Christianity it could have become more significant than previously. It could have remained as one of the few ritual performances in the lives of the ancestors of the Estonians from pre-Christian times that both secular and ecclesiastic authorities tolerated. In this case elements from a variety of rituals may have coalesced with it.

The ritual drinking of beer and/or the offering of beer probably had its place at weddings as well as it did on calendrical feast days. In this respect the names for many Udmurt feast days are revealing; tolsur 'winter beer', nowadays it falls on Christmas Day, gery sektan 'giving the plough a treat', a spring ploughing feast, kuarsur 'leaf beer', the non-Christened Udmurts of the Alnash region celebrate this on 12 July, St. Peter's Day, guzhem juon 'summer drinkingtime', and siz'öl juon 'fall drinking', a fall feast at the end of November or beginning of December.

If we accept that the songs 'The Lost Brush' and 'the Great Oak' are connected to the feast that took place at the summer solstice then the individual who spills the beer might very well be that same maiden with the golden comb / sun going into the crowns of the trees. The activities (such as sea sweeping) themselves might point to solstice magic. What is important is that an activity with which people attempt to procure a reasonable amount of fertility in their sphere can cause great perturbations within the realm of the deities. We could say that in this case the old principle quod licet Jovi non licet bovi is working backwards. According to the widespread principles at work in the mythologies of very many peoples, the gods have established the earthly order by overstepping existing laws either unintentionally or without taking into consideration their own powers. By totally ignoring the laws existing at the time of creation, light itself or the deity who rules it, either creates darkness or descends into the realm of the dead so that some hero (saviour) has to intervene who will vanquish the darkness or bring back the deity to life. Just so it can happen all over again and again. 


\section{COMMENTS}

${ }^{1}$ E. Setälä suggests that there are two separate Sampo-cycles. One of them deals with the forging and theft of the Sampo as a sequel to the creation of the world, the second is centred around the courting of the Maiden of the North and presents the making of the Sampo as one of the many tasks required to win the maiden.

${ }^{2}$ For example in the lines 'I enter my city shaped like a running horse, into the city shaped like a striding horse. I am there protecting the souls of the girls, I am there protecting the souls of the boys' (Steinitz 1939: 263) lets the listener know that who we have here is the Elder of the Holy City.

${ }^{3}$ The Udmurt word vozho is in relationship with the Old Permian vezha - sacred (cf. ien vezha lov the Holy Spirit, vezha kuima the Holy Trinity, vezha lun Sunday). To be sure, the Udmurt term vozhodyr may be translated from the Russian word sviatki (from sviato-sacred). For us it is important that supernatural guests of such a sacred time - Udmurt vozho's and Komi Permyak chud's look like little furry devils. However, they are not in relationship with witches and evil forces acting on the eve of Maundy Thursday. We have not data to connect Udmurt vozho's directly with souls of the dead, but in Komi folklore the chud's are often regarded as mythical ancestors or heroes of the Komi people.

${ }^{4}$ A sword or cross in the sky was a sign of war:

If there is some sort of figure around the sun, for example a cross, then it was thought that war would come. In 1914 the owner of Künnapistu farm in Valgjärve township saw a cross in the sky next to the sun. ERA II 203, 275 (4) Ote.

War marks are different: when the world war was happening here, then here at Siimu there was a light red cross overhead and above Tallinn there was a white sword. ERA II 77, 283 (77) Hag.

${ }^{5}$ Lit. blood wedding. 


\section{References and sources}

\section{Manuscript}

ERA $=$ The collection of Estonian Folklore Archives

\section{Printed}

Ariste, P. 1969. Vadja rahvakalender. ENSV TeadusteAkadeemia Emakeele Seltsi Toimetised nr. 8. Tallinn.

ER I = Eesti rahvalaulud Dr. Jakob Hurda ja teiste kogudest. Esimene köide. Eesti Kirjanduse Seltsi Toimetused nr. 21. Tartu 1926.

ERIA I:2 = Eesti rahvalaulud. Antoloogia . Toimetanud Ü. Tedre. I köide, 2. vihik. Tallinn 1969.

ERIA II:1 = Eesti rahvalaulud. Antoloogia. Toimetanud Ü. Tedre. II köide, 1. vihik. Tallinn 1970.

KKR I = Karjalan kansan runot I. Kalevalanaiheiset kertovaiset runot. Kokoonpannut V. Jevsejev. Tallinn 1976.

Kuusi 1963 = Kirjoittamaton kirjallisuus. Suomen kirjallisuus I. Keuruu.

Kuusi 1980 = Kuusi, M., Honko, L., Virtanen, L., Pentikäinen, J. Perinteentutkimuksen perusteita. Porvoo.

Kuusi, M. 1994. Mind and Form in Folklore. Selected Articles. Studia Fennica. Folkloristica 3. Helsinki.

Lintrop, A. 1997. Väike mos'-naine. Ühe (muinas)jutu lugu. Mäetagused nr. 3. Tartu.

Pervukhin, N. G. 1888. Eskizy predanii i byta inorodcev Glazouskogo uezda. Eskiz 2. Viatka.

RK III = Eesti rahvakalender III. Koostanud M. Hiiemäe. Tallinn 1984.

RK IV = Eesti rahvakalender IV. Koostanud M. Hiiemäe. Tallinn 1985.

Sarmela, M. 1995. Suomen perinneatlas. Suomen kansankulttuurin kartasto 2. Folklore. Suomalaisen Kirjallisuuden Seuran Toimituksia 587. Helsinki

Setälä, E. N. 1932. Sammon arvoitus. Isien runous ja usko I. Helsinki.

SKVR $\mathrm{I}_{4}=$ Suomen Kansan Vanhat Runot I. Vienan läänin runot 4. Julkaissut A. R. Niemi. Suomalaisen Kirjallisuuden Seuran Toimituksia 121. Helsinki 1921. 
SKVR III 1 = Suomen Kansan Vanhat Runot III. Länsi-Inkerin runot 1. Julkaissut V. Salminen. Suomalaisen Kirjallisuuden Seuran Toimituksia 139. Helsinki 1915.

SKVR $\mathrm{IV}_{2}=$ Suomen Kansan Vanhat Runot IV. Keski-Inkerin runot 2. Julkaissut V. Salminen. Suomalaisen Kirjallisuuden Seuran Toimituksia 140. Helsinki 1926.

SKVR VII 4 = Suomen Kansan Vanhat Runot VII. Raja- ja PohjoisKarjalan runot 4. Julkaisseet K. Krohn ja V. Alava. Suomalaisen Kirjallisuuden Seuran Toimituksia 143. Helsinki 1933.

SKVR XV = Suomen Kansan Vanhat Runot XV. Runoja Henrik Florinuksen, Kristfrid Gananderin, Elias Lönnrotin ja Volmari Porkan kokoelmista. Toimittaneet M. Kuusi ja S. Timonen. Suomalaisen Kirjallisuuden Seuran Toimituksia 685. Helsinki 1997.

Steinitz, W. 1939. Ostjakische Volksdichtung und Erzählungen aus Zwei Dialekten. 1. Teil. Õpetatud Eesti Seltsi Toimetused XXXI. Tartu.

VK III:1 = Vana Kannel III. Kuusalu vanad rahvalaulud I. Toimetanud H. Tampere. Tallinn 1938.

VK VI:1 = Laugaste, E. Vana Kannel VI:1. Haljala regilaulud. Tallinn 1989. 